\title{
Is It Time to Revisit Trademark Misuse?
}

\author{
By Scott H. Brown \\ Volume XI - Spring 2011 \\ Copyright (C) Pittsburgh Journal of Technology Law and Policy
}

\begin{abstract}
In the recent cases of Georgia-Pacific Consumer Products, L.P. v. Von Drehle Corporation and Georgia-Pacific Consumer Products, L.P. v. Myers Supply, Inc., Georgia-Pacific tried to use its trademarks to establish a tying relationship between its paper towels and its paper towel dispensers. This article reviews these cases by posing a hypothetical situation and then giving the reader a review of trademark basics, the doctrine of contributory trademark infringement, antitrust considerations, and IP misuse. The article then offers a revised trademark misuse test, and relooks at the Georgia-Pacific cases using this revised trademark misuse test.
\end{abstract}




\title{
Is It Time to Revisit Trademark Misuse?
}

\author{
By Scott H. Brown ${ }^{\# \#}$ \\ Volume XI - Spring 2011 \\ Copyright (C) Pittsburgh Journal of Technology Law and Policy
}

\section{INTRODUCTION}

Manufacturers of products that require replacement parts or the refilling of supplies (commonly referred to as "consumables") have long sought ways to force consumers to purchase those consumables only from the original manufacturer. In other words, a product's manufacturer wants to "tie" the purchase of the consumables to - and only to - that manufacturer. Over the years, the manufacturers have used contractual limitations, ${ }^{1}$ as well as patents $^{2}$ and copyrights ${ }^{3}$ as weapons against competitors to ensure compliance with their desired tying relationships. Not too surprisingly, courts have taken a dim view of these tying relationships, often finding that they violate the antitrust laws. ${ }^{4}$ Being ever resourceful, the manufacturers have sought out new means of establishing their desired tying relationships, with the newest weapons being trademarks. This article offers a revised test that can be used to stop trademarks from being improperly used to establish a tying relationship to consumables.

\footnotetext{
\# Chief Intellectual Property Counsel, Weatherford International Ltd. Guest lecturer, University of Houston Law Center. J.D., University of Tulsa; B.S., Southern Methodist University.

\#\# The author would like to thank Craig Joyce and Paul Krieger of The University of Houston Law Center for their assistance and encouragement.

${ }^{1}$ See, e.g., Class Action Complaint for Violations of Section 1 of the Sherman Act; Jury Trial Demanded Action Against Ganz, Inc., Nuts for Candy v. Ganz Inc., No. 3:08CV08-2873 (N.D. CA) (filed June 9, 2008).

2 See, e.g., Morton Salt Co. v. G.S. Suppinger Co., 314 U.S. 488 (1942).

${ }^{3}$ See, e.g., Lexmark Int'1, Inc. v. Static Control Components, Inc., 387 F.3d 522 (6 ${ }^{\text {th }}$ Cir. 2004).

${ }^{4}$ Comm. on Antitrust \& Trade Regulation, Antitrust "Market Power" and Intellectual Property: Why FTC and DOJ Action is Necessary, 58 THE RECORD 11 (2003).
} 


\section{HYPOTHETICAL SITUATION}

Let us start this discussion with a hypothetical situation. ${ }^{5}$

Suppose that E-Normous Inc. ("E-N") is one of the largest computer companies in the world and sells its computers to businesses and home consumers. E-N tries to give the impression to the public that it supports the idea of "open framework" and plug-and-play usage of third-party peripheral equipment that can be connected to an E-N computer. However, in fact, E-N would like to control what can and cannot be connected to an E-N computer. For example, E-N has its own brand of memory sticks or thumb drives (external memory that can connect to a computer's USB port). E-N would love to find a way to prevent other companies' thumb drives from being connected to an E-N computer.

E-N sells a new high-end "FLASH" brand computer that has a clean Euro-look, lots of memory, and a very fast CPU. The FLASH computer also includes a sensor that detects whether or not an E-N-brand thumb drive is connected to it. If a third-party thumb drive is connected, an annoying message appears on the screen to say that the computer "might experience problems" with the non-E-N brand thumb drive. A large label is included on the FLASH computer advising the user that "E-N strongly advises that only genuine E-N brand thumb drives be used."

Almost Decent Ltd. (“AD") is the largest seller of thumb drives in the world, primarily because $\mathrm{AD}$ sells its thumb drives for the lowest prices. The low price also brings along a somewhat mixed reputation for quality. As expected, the AD thumb drives are often used on E$\mathrm{N}$ brand computers, and now on the FLASH computer. Internal testing at AD showed that their thumb drives worked fine on all of E-N's previous computers. However, when an AD thumb

\footnotetext{
5 This example is strictly hypothetical, and any similarity between it and existing companies is coincidental and made only for the purpose of illustrating how trademark misuse issues could arise.
} 
drive was tested with the new FLASH computer, occasionally there was an "operational issue," but nothing out of the ordinary for a new computer.

Into this arena comes our consumer, who joyfully purchased one of the very first FLASH computers. After only a few hours of running the FLASH computer, the consumer found that the FLASH computer locked up almost every time an AD thumb drive was plugged in. The consumer performed several tests and found that the same AD thumb drive worked fine with another brand of computer, including another computer from E-N. So, the consumer believed that the problem was not with $\mathrm{AD}$, but with E-N. After several long and frustrating hours of waiting and then finally talking to E-N's customer support, the consumer was no better off than before. E-N's customer support insisted that the problem was with the AD thumb drive, not with E-N's FLASH computer. The consumer insisted that the problem was with the FLASH computer. In actuality, no one will ever know the real root cause of this problem.

The consumer was so frustrated with the FLASH computer that the consumer placed notices on several Internet blogs about the FLASH computer locking up when an AD thumb drive was inserted. Soon, many other consumers around the world found cold comfort to know that their FLASH computers were not alone in locking up when using the AD thumb drives. Even though the consumers had all read the warnings from E-N about only using E-N thumb drives, they were convinced that somehow E-N was diabolically to blame. Some of these consumers expressed their frustration with statements such as "E-N's FLASH IS A FLOP" and "E-N = EVIL NATION!" E-N took notice of these negative comments, and put out its own online statements advising owners of its FLASH computers to not use "off-brand thumb drives." Consumers became even more indignant about E-N telling them to give up their beloved AD 
thumb drives. When the press started writing articles critical of E-N's tactics, public sentiment grew overwhelmingly against E-N and for AD.

With all of the negative public comments being made, E-N's president told the in-house Intellectual Property (IP) Counsel: "Find a way to stop people from installing AD thumb drives on our FLASH computers!" The IP Counsel stated that AD's (alleged) poor quality was “harming E-N's valuable IP property." E-N's president was intrigued, and asked for more details. The IP Counsel continued by saying that, under the doctrine of contributory trademark infringement, AD's poor quality was bleeding over and causing consumers to think negatively of the E-N brand. Specifically, AD knowingly sold "low quality" thumb drives that they knew would be installed on FLASH computers, and which would then result in the computer experiencing "operational issues." The public would be confused as to who was to blame. Thus, E-N's ability to control its reputation would be adversely affected, and its stock price might decline.

E-N's President was enthralled with this newfound legal weapon because E-N could possibly finally accomplish its goal of having only E-N thumb drives used with the FLASH computers. "We will make millions of dollars," said the President as he slapped the IP counsel on the back. The next day, E-N filed suit against AD claiming contributory trademark infringement. Due to E-N's colossal size and astonishing legal budget, AD could not fight the battle and soon was forced out of business.

If $\mathrm{AD}$ never actually did anything wrong (e.g., AD never used E-N's trademarks), then why should E-N be able to bring a legal action using the trademark laws? In the recent trademark cases brought by Georgia-Pacific, ${ }^{6}$ Georgia-Pacific sued competitors that made and/or installed lower-priced paper towels sized to fit into Georgia-Pacific's enMotion-brand paper

\footnotetext{
${ }^{6}$ See Von Drehle, 618 F.3d 441 (4th Cir. 2010); Myers Supply, 621 F.3d 771 ( $8^{\text {th }}$ Cir. 2010).
} 
towel dispensers. Georgia-Pacific wanted to tie their paper towels (the "consumable") to their enMotion dispensers, and thereby prevent competitors from supplying the consumable. Despite the fact that its competitors did not use Georgia-Pacific's trademarks in any way, Georgia-Pacific used the doctrine of contributory trademark infringement against them.

Is this a fair and proper use of the trademark laws to establish a tying relationship for consumables? In other words, is this trademark misuse?

\section{Trademark Basics}

Before examining whether Georgia-Pacific's actions might be considered trademark misuse, it would be useful to discuss the function of a trademark and its primary purposes. First of all, the laws of the United States regarding trademarks are found in the Lanham Act. ${ }^{7}$ Section 1127 of the Lanham Act states:

The term "trademark" includes any word, name, symbol, or device, or any combination thereof-(1) used by a person ...to identify and distinguish his or her goods, including a unique product, from those manufactured or sold by others and to indicate the source of the goods, even if that source is unknown. ${ }^{8}$

Trademark rights are established through the use of a mark in commerce, and continued use of the trademark is necessary to maintain the owner's rights in such mark. ${ }^{9}$ The owner of a trademark is entitled to the exclusive right to use the mark, which includes the ability to prevent the use by another of a confusingly similar mark. ${ }^{10}$

\footnotetext{
${ }^{7}$ U.S. Trademark Act of 1946, Pub. L. No. 79-489, 60 Stat. 427 (codified as amended in scattered sections of 15 U.S.C).

8 15 U.S.C. $\S 1127$ (2006).

${ }^{9} \mathrm{Id}$.

${ }^{10} 15$ U.S.C. $\S 1114$ (1)(a) (2010).
} 
Trademark laws arise from the old common law tort of deceit or "passing off," which then further evolved into the concept of unfair competition. ${ }^{11}$ Trademarks primarily have two purposes: (a) to protect consumers from confusion, and (b) to protect the trademark owner from others who would try to use the goodwill of the other to sell their own products. The Supreme Court stated that the trademark laws:

reduce the customer's costs of shopping and making purchasing decisions, for it quickly and easily assures a potential customer that this item - the item with this mark - is made by the same producer as other similarly marked items that he or she liked (or disliked) in the past. At the same time, the law helps assure a producer that it (and not an imitating competitor) will reap the financial, reputation related rewards associated with a desirable product. ${ }^{12}$

\section{CONTRIBUTORY TRADEMARK INFRINGEMENT}

Georgia-Pacific used the doctrine of contributory trademark infringement against its competitor in the paper towel business. Contributory trademark infringement is a legal doctrine that allows a trademark owner to sue a party who does not directly infringe the owner's trademark, but in some manner negatively affects the value of the trademark. This doctrine is not provided for in the Lanham Act, ${ }^{13}$ but arose from the common law of torts to become a judicially created doctrine. Specifically, "[1]iability for trademark infringement and unfair competition may be extended beyond those who actually sell goods with the infringing mark, to include those contributory infringers who knowingly cooperate in illegal and tortious activity."

\footnotetext{
${ }^{11}$ RESTATEMENT (THIRD) OF UNFAIR COMPETITION $\$ 1$ (1995).

${ }^{12}$ Qualitex Co. v. Jacobson Prods. Co. Inc., 514 U.S. 159, 163-64 (1995).

${ }^{13}$ See U.S. Trademark Act of 1946, 60 Stat. 427.

${ }^{14}$ J. Thomas MCCARThy, MCCARThy ON TRADEMARK AND Unfair COMPETiTion $\S \S 25: 17-184^{\text {th }}$ ed. (2009).
} 
The most significant case describing this doctrine is known simply as "the Inwood case". ${ }^{15}$ Inwood involved a trademark infringement claim brought by Ives Laboratories (Ives), a prescription drug manufacturer, against Inwood Laboratories (Inwood), a generic drug manufacturer. Ives manufactured the patented drug cyclandelate, and sold it under the registered trademark "Cyclospasmol." After Ives' patent expired, several generic drug manufacturers began selling their generic drugs in capsules that looked almost exactly like the Cyclospasmol capsules. $^{16}$

Ives sued the generic manufacturers, saying that some pharmacists had sold generic drugs mislabeled as Cyclospasmol. Ives argued that Inwood's use of look-alike capsules contributed to the pharmacies' infringing activities. The district court denied Ives's request for injunctive relief, and the Second Circuit affirmed, but sent the case back to the district court. On remand, the district court again entered judgment in favor of the generic drug companies. On its second appeal, the Second Circuit reversed the district court's judgment, reviewed the evidence itself, and concluded that a Lanham Act violation occurred. The generic manufacturers then petitioned the Supreme Court for a writ of certiorari. The Supreme Court found that the Second Circuit had erred in setting aside the district court's findings of fact and providing its own view of the evidence.

The Supreme Court reaffirmed the concept of contributory trademark infringement by stating:

As the lower courts correctly discerned, liability for trademark infringement can extend beyond those who actually mislabel goods with the mark of another. Even if a manufacturer does not directly control others in the chain of distribution, it can be held responsible for their infringing activities under certain circumstances. Thus, if a manufacturer or distributor intentionally

\footnotetext{
${ }^{15}$ Inwood Laboratories, Inc. v. Ives Laboratories, Inc., 456 U.S. 844, 853-54 (1982).

${ }^{16}$ Id. at 847 .
} 
induces another to infringe a trademark, or if it continues to supply its product to one whom it knows or has reason to know is engaging in trademark infringement, the manufacturer or distributor is contributorily responsible for any harm done as a result of the deceit. ${ }^{17}$

Since Inwood, the doctrine of contributory trademark infringement has been used in a wide variety of cases involving travel agencies, sports score tracking services, fashion designs, and high-end consumer products. ${ }^{18}$ Recently, the majority of the cases have involved Internet domain names. In one example, Gucci, the expensive fashion house, sued an Internet Service Provider (ISP) in federal district court in New York. ${ }^{19}$ The court denied the ISP's motion to dismiss Gucci's contributory trademark infringement claim since Gucci had repeatedly notified the ISP that its customers were infringing Gucci's trademarks and the ISP failed to take corrective action.

\section{The Georgia-PaCific CASES}

The two related cases that are the subject of this article are: Georgia-Pacific Consumer Products, L.P. v. Von Drehle Corporation ${ }^{20}$, and Georgia-Pacific Consumer Products, L.P. v. Myers Supply, Inc.. ${ }^{21}$ Looking first at the Fourth Circuit case (Georgia-Pacific v. Von Drehle), the facts are that Georgia-Pacific was a manufacturer of paper products and paper towel dispensers. In 2002, Georgia-Pacific introduced its enMotion-brand paper towel dispenser with a sensor that detected the user's hand when placed under the dispenser. When a hand was

\footnotetext{
${ }^{17}$ Id. at $853-54$.

${ }^{18}$ For additional examples, see: (a) Brian D. Kaiser, Contributory Trademark Infringement By Internet Service Providers: An Argument For Limitation, 7 J. OF TECH. L. \& POL'Y 4 (2002), and (b) Jane Coleman, Secondary Trademark Infringement, SECONDARYTRADEMARKINFRINGEMENT.COM, http://www.secondarytrademarkinfringement.com (last visited Mar. 1, 2011).

${ }^{19}$ Gucci Am., Inc. v. Hall \& Assocs., 135 F. Supp. 2d 409, 410 (S.D.N.Y. 2001).

${ }^{20}$ Georgia-Pac. Consumer Products, L.P. v. Von Drehle Corp., 618 F.3d 441 (4 ${ }^{\text {th }}$ Cir. 2010).

${ }^{21}$ Georgia-Pac. Consumer Products, L.P. v. Myers Supply, Inc., 621 F.3d 771 ( $8^{\text {th }}$ Cir. 2010).
} 
detected, the enMotion dispenser would dispense a paper towel without need for the user to touch the dispenser itself. In addition, Georgia-Pacific made a special size of paper towel, of a high quality with a fabric-like feel, to fit within and be dispensed only by the enMotion dispenser. Further, the enMotion dispensers prominently displayed several enMotion registered trademarks. $^{22}$

Using a business plan novel to the paper towel industry, Georgia-Pacific only leased the enMotion dispensers to janitorial supply distributors, who in turn subleased the enMotion dispensers to their end-user customers (e.g., hotels, stadiums, restaurants, etc.). Georgia-Pacific sold the special paper towels for use in the enMotion dispensers to the same janitorial supply distributors, who in turn sold the paper towels to the end-user customers. The lease and sublease agreements stated that only Georgia-Pacific's enMotion paper towels could be used in the enMotion dispensers. ${ }^{23}$

In 2005, Von Drehle Corporation ("Von Drehle") started selling to distributors a lower quality paper towel (called "810-B Toweling") sized for use within Georgia-Pacific's enMotion dispensers. Georgia-Pacific filed suit against Von Drehle alleging contributory trademark infringement and unfair competition, because Von Drehle's 810-B Toweling's poor quality created post-purchase confusion as to the source of such toweling among restroom visitors. The district court granted summary judgment in favor of Von Drehle, and Georgia-Pacific appealed.

The Fourth Circuit explained how Georgia-Pacific had tried to tie the enMotion dispensers to the enMotion paper towels in the minds of consumers. The court said that for many years, Georgia-Pacific had sold "universal dispensers," which were intended to accept

\footnotetext{
${ }^{22}$ For a depiction of the trademarks at issue, see Von Drehle Corp., 618 F.3d at 445.

${ }^{23}$ Id.
} 
paper toweling from multiple manufacturers. ${ }^{24}$ However, Georgia-Pacific changed this business model when it introduced a non-universal dispenser tied directly to the Georgia-Pacific's enMotion trademarks, so that a restroom visitor would come to expect the enMotion dispenser to dispense only the high quality enMotion paper towels. The court analogized Georgia-Pacific's goal to a soda fountain labeled with the Coca-Cola trademarks, which the user expects to dispense only genuine Coca-Cola products. ${ }^{25}$ Georgia-Pacific claimed that Von Drehle's intentional conduct was to market its 810 -B Toweling to distributors and end-user customers for use with enMotion dispensers, resulting in post purchase confusion as to the source of toweling dispensed. $^{26}$

The appellate court noted that Von Drehle itself did not physically place the 810-B Toweling in the enMotion dispensers, so Georgia-Pacific's claims needed to be analyzed under the doctrine of contributory, not direct, trademark infringement. As background, the court characterized the Inwood case and said:

a manufacturer or distributor could be held liable to the owner of a trademark if it intentionally induced a merchant down the chain of distribution to pass off its product as that of the trademark owner's or if it continued to supply a product which could readily be passed off to a particular merchant whom it knew was mislabeling the product with the trademark owner's mark. ${ }^{27}$

The court inquired if there was sufficient evidence for a reasonable jury to find that Von Drehle's customers placing the 810-B Toweling into Georgia-Pacific's enMotion dispensers constituted trademark infringement. ${ }^{28}$ The court found that Georgia-Pacific's enMotion trademarks were registered and presumably valid, and that by placing Von Drehle's 810-B Toweling in Georgia-

\footnotetext{
${ }^{24} I d$. at $445-46$.

${ }^{25} I d$. at 446.

${ }^{26} I d$. at 448.

${ }^{27}$ Von Drehle, 618 F.3d at 451 (quoting Sony Corp. of Am. v. Universal Studios, Inc., 464 US 417, 439, n. 19 $(1984))$.

${ }^{28}$ Von Drehle, 618 F.3d at 451.
} 
Pacific's enMotion dispensers, Von Drehle's end-user customers used one or more of GeorgiaPacific's trademarks in commerce. ${ }^{29}$

The court then asked whether the end-user customers used Georgia-Pacific's trademarks in a manner likely to cause confusion among the relevant public. The lower court rejected Georgia-Pacific's legal theory that restroom visitors who consumed toweling dispensed from enMotion dispensers constituted the relevant audience for purposes of the likelihood-ofconfusion analysis. The appellate court disagreed with the lower court and said that confusion among the non-purchasing public could be reviewed if it could "be shown that public confusion will adversely affect the plaintiff's ability to control his reputation among its laborers, lenders, investors, or other groups with whom plaintiff interacts." 30 The court said that the loss of the ability to control the quality of the toweling used in Georgia-Pacific's enMotion dispensers put Georgia-Pacific at risk of injury to its enMotion trademarks.

The appellate court concluded that Georgia-Pacific had presented sufficient evidence for a reasonable jury to find a likelihood of confusion among restroom visitors as to the source of the paper toweling being dispensed from enMotion dispensers when Von Drehle's 810-B Toweling was being dispensed. Proof that Von Drehle's 810-B Toweling was inferior to Georgia-Pacific's enMotion paper towels was unnecessary in order to establish confusion; however, the court noted that Von Drehle had received complaints about the poor quality of its 810-B Toweling. ${ }^{31}$ Therefore, the appellate court vacated the lower court's grant of summary judgment in favor of Von Drehle with respect to Georgia-Pacific's Lanham Act and unfair-competition claims, and remanded for further proceedings consistent with their opinion. ${ }^{32}$

\footnotetext{
${ }^{29}$ Id. at 449 .

${ }^{30}$ Id. at 453 (quoting Perini Corp. v. Perini Constr., Inc., 915 F.2d 121, 128 (4 ${ }^{\text {th }}$ Cir. 1990)).

${ }^{31} I d$. at 455.

${ }^{32}$ Von Drehle, 618 F.3d at 457-58.
} 
In the Eighth Circuit case (Georgia-Pacific v. Myers Supply), the facts were essentially the same as in the Fourth Circuit's case above. However, the appellate court noted at the outset that Georgia-Pacific also manufactured "universal" towel dispensers, e.g., nonproprietary dispensers that also bear Georgia-Pacific's trademarks (but not the enMotion trademarks). The court noted that it was common practice in the industry, and not improper, to put one brand of towels in an unleased, universal dispenser displaying a different manufacturer's trademarks - a practice called "stuffing." Further, Georgia-Pacific sold towels for use in other manufacturers' trademarked dispensers. ${ }^{33}$

In 2003, Georgia-Pacific leased its enMotion dispensers to one of its distributors, Brown Janitorial Supply. Brown distributed the enMotion dispensers to businesses, churches, and school districts. Myers, the defendant in this case, was also a distributor of other manufacturers' paper-towels and paper towel dispensers. In 2007, Myers began selling Von Drehle Corporation's (Von Drehle's) 810-B Toweling for use in Georgia-Pacific's enMotion dispensers. Myers knew "with 99 percent" certainty that the 810-B Toweling would be used in enMotion dispensers. ${ }^{34}$ Georgia-Pacific sent Myers a cease-and-desist letter stating that enMotion dispensers were property of Georgia-Pacific and subject to lease and sublease agreements. Georgia-Pacific filed suit and accused Myers of trademark infringement and tortious interference with Georgia-Pacific's distributors and the end-user purchasers. After a bench trial, the district court ruled for Myers on the contributory infringement claim, finding no likelihood of confusion by consumers.

Note that the district court had earlier granted summary judgment against Georgia-Pacific on the tortious interference claim, finding that Georgia-Pacific could not prove that Myers

\footnotetext{
${ }^{33}$ Myers Supply, 621 F.3d at 773.

${ }^{34} \mathrm{Id}$.
} 
intentionally caused the end-users to breach sublease agreements, or that its conduct was improper. $^{35}$

To prove contributory infringement, Georgia-Pacific had to establish that Myers continued to supply towels to its customers with knowledge that they were engaging in trademark infringement with the paper towels. There was no dispute that Myers knew that its customers were putting 810-B Toweling in enMotion dispensers. The district court only needed to determine whether this action infringed Georgia-Pacific's trademarks. The district court found no likelihood that consumers would be confused and believe that the trademark on the dispenser indicated the source of the towels inside. Relying on testimony that it was common in the industry to put one brand of towel in a dispenser of a different brand ("stuffing"), the district court found no intent to confuse the public, by either the end-users or Myers. ${ }^{36}$ Further, the district court found that there was no actual confusion in the marketplace because the end-users were fully aware of the brand of towel they stuffed into their dispensers, thus there was no actual confusion as to the source of the towel - a determination unchallenged by Georgia-Pacific. ${ }^{37}$

While the district court reviewed the surveys to show evidence of confusion, the surveys were not found to be overly relevant. The testimony of industry veterans, including a manager from Georgia-Pacific, regarding the commonality and acceptance of "stuffing," was considered highly relevant. ${ }^{38}$ The court said that whether or not a towel dispenser was leased had no bearing on the actual confusion by the bathroom consumer; as there was no evidence that bathroom

\footnotetext{
${ }^{35} I d$. at 774 .

${ }^{36}$ Id. at 775 .

${ }^{37} \mathrm{Id}$.

${ }^{38}$ Id. at 776.
} 
consumers knew whether the dispenser they were using were leased or not. Finding that the district court had not committed clear error, the appellate court affirmed the lower court. ${ }^{39}$

In the Georgia-Pacific cases discussed above, the two fact patterns and evidence were essentially the same, but there were different outcomes for two primary reasons. First, in the Fourth Circuit case, the outcome was an overturning of the district court's grant of a motion for summary judgment on the issue of contributory infringement, and a remand back to the district court. On the other hand, in the Eighth Circuit case, the appellate court was reviewing the decision made after a bench trial. Second, the Eighth Circuit gave greater weight to the industry custom of "stuffing" (e.g., it was acceptable for Georgia-Pacific to stuff other companies' dispensers) than to the survey evidence (e.g., that a majority thought the brand of towel was the same as the brand of the dispenser, and thus a poor quality towel meant that it was from a poor quality brand of dispenser).

\section{Antitrust Considerations}

Suppose that instead of poor quality paper towels, Von Drehle made a paper towel superior in quality to the paper towels offered by Georgia-Pacific for use in their enMotion dispensers. Arguably, there would be no negative implications against the enMotion trademarks. However, according to the survey evidence offered by Georgia-Pacific in both cases above, it would not matter, as the consumer would still possibly think that the paper towels dispensed from the Georgia-Pacific dispensers were from Georgia-Pacific. What then would be the harm to Georgia-Pacific? Looking at this scenario purely from a trademark perspective, there would be no harm to Georgia-Pacific (and to the restroom user) as a high quality paper towel was

\footnotetext{
${ }^{39}$ Id. at $777-8$.
} 
dispensed. However, in the above two cases, it can be argued that Georgia-Pacific did not confine its analysis to whether or not its trademarks were harmed. Georgia-Pacific used its trademarks as a weapon to restrict which paper towels were dispensed from its enMotion dispensers. In other words, Georgia-Pacific tried to "tie" the purchase of unprotected paper towels (the "consumable") to the lease of its enMotion dispensers.

This type of "tying" arrangement arguably runs afoul of the antitrust laws. The Sherman Act provides:

Every contract, combination in the form of trust or otherwise, or conspiracy, in restraint of trade or commerce among the several States, or with foreign nations, is declared to be illegal. ${ }^{40}$

Courts have tried to limit "tying" for many years, but have struggled on how to use the antitrust laws to prevent abuses by intellectual property owners (and their competitors), partly because there are so many overlaps and contradictions between the two bodies of law. ${ }^{41}$

A tying arrangement occurs when, through a contractual or technological requirement, a seller conditions the sale or lease of one product or service on the customer's agreement to take a second product or service. Although courts long have expressed concern that tying might enable firms to use monopoly power in one market as leverage to curb competition, and thereby acquire monopoly power in a second market, the courts have slowly become more comfortable with the idea that tying is not always bad. ${ }^{42}$ For example, tying was once thought of as a per se violation of the antitrust laws, but the Supreme Court has ruled that tying is illegal only if specific conditions are met, including proof that the defendant has market power over the tying product. ${ }^{43}$

\footnotetext{
${ }^{40} 15$ U.S.C. $\$ 1$ (2006).

${ }^{41}$ For an excellent overview, see Daniel Gifford, The Antitrust/Intellectual Property Interface: An Emerging Solution To An Intractable Problem, 31 HofstRA L. REV. 363 (2003).

${ }^{42}$ Illinois Tool Works Inc. v. Indep. Ink, Inc., 547 U.S. 28, 45 (2006).

${ }^{43}$ Jefferson Parish Hosp. Dist. No. 2 v. Hyde, 466 U.S. 2, 12 (1984); Ill. Tool Works, 547 U.S. at 44.
} 
The impact of the courts moving away from the per se illegality of tying arrangements is proving fertile ground for legal scholars. ${ }^{44}$

The issue of an antitrust violation by Georgia-Pacific was raised in one of the district court decisions, but was not addressed on appeal. Judge Wilson wrote in his concurring opinion of the Fourth Circuit case (Georgia-Pacific v. Von Drehle): ${ }^{45}$

In the district court, von Drehle counterclaimed against GeorgiaPacific for violations of $\S 1$ of the Sherman Act, 15 U.S.C. $\S 1$, and $\S 3$ of the Clayton Act, 15 U.S.C. $\S 14$, allegedly carried out through illegal tying arrangements in "the away from home market in the United States for 'hands free' (or 'touchless') dispensers of hand wound paper towels (the 'tying product'), and the market for hard wound paper towels (the 'tied' product). The district court granted Georgia-Pacific's motion for summary judgment on the Clayton Act claim because "end users [were] purchasing paper towels for the enMotion dispenser from von Drehle," and consequently there was no "evidence of actual coercion by the seller that forced the buyer to accept the tied product."...It granted summary judgment on the Sherman Act claim because "von Drehle has competed favorably with GP in the sale of paper towels for the enMotion dispenser" and could show no injury... But von Drehle did not cross-appeal on this issue, and the matter will have to play out (if it is to play out at all) on another day and, perhaps, on a different stage. ${ }^{46}$

Note that the defendants did not argue that the Georgia-Pacific trademarks themselves were somehow used in violation of the antitrust laws. Perhaps the defendants recognized that for a defendant to prevail on an antitrust trademark misuse defense, the defendant has to show that "...the mark itself has been the basic and fundamental vehicle required to accomplish the violation" and "the trademark, as distinguished from collateral activities with respect to goods

\footnotetext{
${ }^{44}$ See Brian Grill, The Treatment of Metering In Antitrust Law: The Supreme Court's Apparent Abolition of the Per Se Rule Against Metering In Ill. Tool Works, Inc. v. Independent Ink, Inc., 2006 WIS. L. REV. 1465; Christian Ahlborn, et al., The Antitrust Economics of Tying: A Farewell To Per Se Illegality, 49 ANTITRUST BulL. 287 (2004); Christina Bohannan and Herbert Hovenkamp, IP And Antitrust: Reformation and Harm, 51 B.C. L. REV. 905 (2010).

${ }^{45}$ See Von Drehle, 618 F.3d 441 ( $4^{\text {th }}$ Cir. 2010).

${ }^{46}$ Von Drehle, 618 F.3d at 458.
} 
bearing the trademark, was itself being used as the prime and effective instrument to effectuate the antitrust activity."

If the tying arrangement attempted by Georgia-Pacific was not, arguably, in violation of the Antitrust Laws, then how can such tying arrangements constitute trademark misuse?

\section{I.P. MISUSES}

As stated before, Georgia-Pacific used its trademarks as a weapon to accomplish a business plan (i.e., tying of the consumables), even though the defendants did not use its trademarks in any manner. This is arguably a classic form of using trademark law in a manner that is not consumer-focused, and thereby beyond the scope of the laws' intention. Kevin J.

Greene of the Thomas Jefferson School of Law wrote:

Today, corporations routinely litigate or threaten to litigate trademark cases that are seemingly devoid of any likelihood of consumer confusion. Particularly, in connection with entertainment-related product such as film and music, the cases seem to come from the theatre of the absurd, and reflect that trademark law is being used in an abusive manner out of sync with any traditional trademark rationale.

The hallmark of such litigation is the overreaching assertion of trademark rights, typically by a large corporate entity against a smaller entity. It has been noted, for example, that the effectiveness of lawsuits to silence corporate critics derives in part from the disparity of resources between the plaintiff corporation and the defendant parody artist. Abusive trademark litigation exists where the claim involves neither a likelihood of confusion as to product source or sponsorship, nor neither free-riding nor morally repugnant unfair competition. ${ }^{48}$

\footnotetext{
${ }^{47}$ Carl Zeiss Stifung v. V.E.B. Carl Zeiss, Jena, 298 F. Supp. 1309, 1314-1315 (S.D.N.Y. 1969).

${ }^{48}$ Kevin J. Greene, Abusive Trademark Litigation and the Shrinking Doctrine of Consumer Confusion: Trademark Abuse in the Context of Entertainment Media and Cyberspace, 27 HARV. J.L. \& PUB. POL'Y 609 (2003).
} 
Trademark misuse, as well as patent and copyright misuse, arises from two general situations: an antitrust violation and/or an improper attempt to extend the scope of the intellectual property right. As discussed above, the lower court in Georgia-Pacific Consumer Products, L.P. v. Von Drehle Corporation $^{49}$ (the Fourth Circuit case) held that Georgia-Pacific did not violate the antitrust laws, ${ }^{50}$ so we will set this issue aside for the purposes of this article.

Before examining the issue of trademark misuse, it is useful to look at the principles of patent and copyright misuse for background. An excellent place to start for patent misuse is Morton Salt Co. v. G.S. Suppinger Co. ${ }^{51}$ In this case, Morton Salt owned a patent on a machine for depositing salt tablets in food cans, and leased these machines to canners on the condition that the canners (lessees) only buy salt from a Morton Salt company. The Supreme Court ruled it per se illegal for a patent holder to "tie" the sale of a patented good to the sale of a non-patented good. The appellate court characterized this conduct as an attempt to improperly enlarge the scope of the patent, and therefore, using its equitable remedies, found that the patentee comes to court with unclean hands. ${ }^{52}$ Using the lexicon of this article, Morton Salt tried to improperly use the patent laws to establish a tying relationship in the supply of consumables.

Through the years, courts have limited various aspects of patent misuse (e.g., in pooling of patents and other patent license arrangements are no longer per se illegal). ${ }^{53}$ However, the doctrine still stands that, with a few caveats, a patentee may not "tie" the sale of a patented product to the sale of a non-patented product, as this is considered an improper extension of the patent right.

\footnotetext{
${ }^{49}$ See Von Drehle, 618 F.3d 441 (4 $4^{\text {th }}$ Cir. 2010).

${ }^{50}$ See Myers Supply, 621 F.3d 771 ( $8^{\text {th }}$ Cir. 2010).

${ }^{51}$ Morton Salt Co. v. G.S. Suppinger Co., 314 U.S. 488 (1942). See also Mercoid Corp. v. Mid-Continent Co., 320 U.S. 661 (1944); Mercoid Corp. v. Minneapolis-Honeywell, 320 U.S. 680 (1944).

${ }^{52}$ Morton Salt, 314 U.S. at 492.

5335 U.S.C. $\S 271(d)(2006)$.
} 
Copyright misuse is similar to patent misuse, as the copyright owner tries to improperly extend the statutory rights associated with the copyrights. The major copyright misuse case is Lasercomb America v. Reynolds. ${ }^{54}$ Lasercomb sold copies of a computer-aided design program that Reynolds licensed. Reynolds found a way to get around the internal security system that limited the number of copies of the software that could be running at the same time, and Lasercomb sued for copyright infringement. Reynolds said that even though it had infringed Lasercomb's copyright, it should not be found liable because Lasercomb had "misused its copyright" by the terms of the license agreement. Specifically, as part of the license agreement, Reynolds had to agree not to develop a competitive design program for 99 years (a term of years longer than the copyright term in effect at that time). ${ }^{55}$ The court found that Lasercomb was trying, in effect, to extend the term and scope of its copyright beyond what copyright law permitted, and that would prevent people from legitimately developing competitive software. These actions were a "misuse of copyrights" by Lasercomb, and the court used its equitable powers to refuse to enforce the copyright against Reynolds. ${ }^{56}$

Another copyright case that should be discussed here is Lexmark International, Inc. $v$. Static Control Components, Inc. ${ }^{57}$ While not usually viewed as a "copyright misuse" case, Lexmark can be considered as an attempt to use the copyright laws to create a tying arrangement with a consumable. In this case, the computer printer maker Lexmark sued Static Control Components, a maker of computer microchips. Static Control made replacement microchips that enabled printer cartridge remanufacturers to refill toner cartridges (i.e., the consumables) for printers and sell them more cheaply than the original equipment manufacturers. Lexmark

\footnotetext{
${ }^{54}$ Lasercomb America v. Reynolds, 911 F.2d 970 (4 ${ }^{\text {th }}$ Cir. 1990).

${ }^{55} I d$. at 973.

${ }^{56} \mathrm{Id}$. at 978 .

${ }^{57}$ Lexmark Int'1, Inc. v. Static Control Components, Inc., 387 F.3d 522 (6 ${ }^{\text {th }}$ Cir. 2004).
} 
claimed that Static Control circumvented Lexmark's access control technologies in violation of the Digital Millennium Copyright Act (DMCA), and infringed its copyrights by reverse engineering its printer toner cartridges in developing its replacement chips for its toner cartridges. ${ }^{58}$ The district court ruled in Lexmark's favor, and Static Control appealed to the Sixth Circuit. The Sixth Circuit ruled in favor of Static Control, holding that some of the Lexmark software did not deserve copyright protection, and the authentication protocol did not protect the software. The appellate court stated that:

Nowhere in its deliberations over the DMCA did Congress express an interest in creating liability for the circumvention of technological measures designed to prevent consumers from using consumer goods while leaving the copyrightable content of a work unprotected. ${ }^{59}$

Judge Merritt said it even more bluntly in his concurring opinion:

By contrast, Lexmark would have us read this statute in such a way that any time a manufacturer intentionally circumvents any technological measure and accesses a protected work it necessarily violates the statute regardless of its "purpose." Such a reading would ignore the precise language - "for the purpose of" - as well as the main point of the DMCA - to prohibit the pirating of copyright-protected works such as movies, music, and computer programs. If we were to adopt Lexmark's reading of the statute, manufacturers could potentially create monopolies for replacement parts simply by using similar, but more creative, lock-out codes. Automobile manufacturers, for example, could control the entire market of replacement parts for their vehicles by including lockout chips. Congress did not intend to allow the DMCA to be used offensively in this manner, but rather only sought to reach those who circumvented protective measures "for the purpose" of pirating works protected by the copyright statute. ${ }^{60}$

The net effect of the Sixth Circuit's decision was to block Lexmark from using the DMCA as a means for tying replacement toner cartridges (the consumables) to the printer manufacturer.

\footnotetext{
${ }^{58} I d$. at 529 .

${ }^{59} I d$. at 549.

${ }^{60}$ Id. at 552 (Merritt, J. concurring).
} 
In reading the Morton Salt case, the Lexmark case, and now the Georgia-Pacific cases, one is struck at the similarities in the facts of each case. Each case involved an I.P. owner who was a manufacturer that sold or leased a device that required refilling or resupply of a consumable (e.g., salt tablets, toner cartridges, and paper towels). In each case, the manufacturer wanted to require the end-users to buy the consumables only from that manufacturer. In each case, the consumable was not primarily protected by a patent, copyright or trademark. Yet, the manufacturer used these intellectual properties to stifle competition in the manufacture and supply of these consumables. The court found the I.P. owner's actions to be improper as respectively constituting patent misuse, an improper extension of the DMCA (copyright misuse) and, at least in one case, inequitable use of the trademark laws (trademark misuse).

\section{What is trademark misuse?}

Courts have had great difficulty in trying to provide a clear definition of "trademark misuse". Part of the problem is that trademarks are primarily created to protect the consumer, yet more recently plaintiff trademark owners and the courts are viewing trademarks as very valuable property that must be protected. ${ }^{61}$ This transformation of trademarks into "property" that must be protected gained momentum especially after passage of the Federal Trademark Dilution Act. $^{62}$ Legal scholars have debated for years whether trademarks are "property."63 And, if a property, how much is it worth? Professors Landes and Posner state:

[T]he brand's reputation for quality and thus the trademark's value depend on the firm's expenditures on product quality, service, advertising, and so on. Once the reputation is created, the firm will

\footnotetext{
${ }^{61}$ Sara Nelson, The Wages of Ubiquity in Trademark Law, 88 IowA L. REV. 731 (2003); Michael Carrier, Cabining Intellectual Property Through A Property Paradigm, 54 DUKE L.J. 1, 74-76 (2004).

${ }^{62} 15$ U.S.C. $\S \S 1125,1127$ (2006).

${ }^{63}$ Marianna Moss, Trademark “Coexistence” Agreements: Legitimate Contracts or Tools of Consumer Deception?, 18 Loy. CONSUMER L. REV. 197, 200-202 (2005).
} 
obtain greater profits, because of repeat purchasers and word-ofmouth references... ${ }^{64}$

One can only imagine how much the marks "Coca-Cola", "Nike", "Apple" and "G.E." are truly worth to their respective corporate owners. Asking the question of whether a trademark is a very valuable "property" is not a theoretical exercise, since if a trademark owner looks at the trademark as a valuable asset that needs to be protected (which is almost always the case), then one can understand the owner doing everything legally possible to protect the goodwill associated with the valuable trademark asset. The owner can then very easily take the next mental step of thinking of that trademark asset as a tool, and then to the final step of looking at the trademark as a weapon. And, if a weapon, then it can be used offensively to thwart competition, as in the E-N and AD hypothetical offered at the beginning of this article. If the trademark is used offensively, for example, to establish a tying relationship for consumables, then what does this have to do with the purposes of a trademark - to protect the consumer from confusion and prevent free-riding on another's goodwill? In other words, is this trademark misuse?

William E. Ridgway's article: Revitalizing The Doctrine of Trademark Misuse provides an excellent summarization of the beginnings and current muddled status of trademark misuse. ${ }^{65}$ In his article, Ridgway suggests an equity-based approach to define and remedy trademark misuse. Ridgway offers the following:

An equity-based approach to the doctrine of trademark misuse should provide clear guidance to courts....Broadly speaking, the elements of trademark misuse should be a trademark holder's:

1) incorrect assertion of rights

2) with an improper purpose.

\footnotetext{
${ }^{64}$ See William M. LANDES \& Richard A. Posner, The EConOmic Structure of InTELleCtual Property 166, 168 (Belknap Press) (2003).

${ }^{65}$ William E. Ridgway, Revitalizing the Doctrine of Trademark Misuse, 21 Berkeley Tech. T.J 1547 (2006).
} 
The first element calls on a court to assess the legal basis of a trademark holder's assertion of rights. The second element requires inquiry into the subjective intent of the trademark holder. If trademark holders do not seek the proper adjudication of the claim upon which the assertion of rights is based, their purpose is improper under the second element. Yet ascertaining the purpose of a trademark holder poses obvious evidentiary problems; thus certain factual situations in which a trademark holder's purpose is unlikely to be related to consumer confusion should raise a presumption of an improper purpose. ${ }^{66}$

With a few tweaks provided below Ridgway's proposed test can be used by courts to eliminate trademarks being improperly used to establish a tying relationship for consumables. Ridgway's test is equity-based, so the courts will become more comfortable exercising their discretionary powers, as opposed to trying to apply the ever-allusive antitrust laws. ${ }^{67}$ In addition, the test remains true to the principles of trademark law by focusing first and foremost on protecting the consumer, as opposed to focusing - as the trademark owners would suggest - on protecting the trademark "property," or worse, on using trademarks as a weapon to establish a tying relationship for consumables.

\section{ReVised TeSt For Trademark Misuse}

This article proposes expanding the Ridgway two-part test above by adding specific questions in the analysis of each of the two parts aimed at preventing trademarks from being used in a scheme to improperly tie a consumable to a product. These specific questions will provide the courts, the public, and manufacturers with clear guidelines as to what constitutes trademark misuse, and thus, what can and cannot be done, especially with regards to the tying of consumables.

The revised test is as follows:

${ }^{66} \mathrm{Id}$. at 1567.

${ }^{67}$ See id. at 1583 (explaining court-based equity remedies). 
A. Is there an incorrect assertion of rights?

1. Is there a valid registered trademark?

2. Who is the relevant consumer or market?

3. Is there direct infringement of the trademark?

- Is the offending mark used in a manner that would cause confusion as to the source of the goods or services in the mind of the relevant consumer or market?

4. If the trademark is not directly infringed, is it indirectly infringed?

- For example, use the contributory infringement analysis.

B. Is there an assertion of rights for an improper purpose?

1. Is the trademark owner's primary goal to prevent confusion in the mind of the relevant consumer or market?

2. Is the intent of the owner to prevent others from: (a) using the goods that bear the trademark, (b) supplying consumables to the goods that bear the trademark, or (c) gaining access to the goods that bear the trademark?

Now, let us look at the Georgia-Pacific cases through the lens of the revised test.

\section{The Revised Test Applied to the Georgia-Pacific Cases}

The first step is to see if there is an incorrect assertion of rights? Another way to ask the question is: what is the assertion of rights, and is it done correctly?

1. Is there a valid registered trademark? In the Georgia-Pacific cases, the courts were provided facts to support a conclusion that Georgia-Pacific owned presumptively valid registered trademarks to "enMotion." Obviously, if there was not a valid trademark at issue, then the whole legal inquiry could be swiftly ended. ${ }^{68}$

2. Who is the relevant consumer or market? The Fourth Circuit looked at this issue more intently than the Eighth Circuit. However, the Fourth Circuit missed the point. The court

\footnotetext{
${ }^{68}$ Von Drehle, 618 F.3d at 451.
} 
accepted the concept that the relevant consumer was the person in the restroom attempting to dry their hands. ${ }^{69}$ So, when this person received a low quality paper towel, they might think poorly of the brand of machine that dispensed that paper towel. If so, so what? This person doesn't buy the paper towels at issue or choose the paper towel dispenser to be used. In fact, this person is merely using something placed in a restroom for their convenience - there is no personal choice as to whether to buy or use a particular brand of a product or service. To argue otherwise would require someone (the trademark owner) to say - with a straight face - that people driving on the highway and finding themselves in need of a restroom will choose which restroom to stop at because that particular restroom offered Crane-brand toilets or dispensed Purell-brand soap.

The only person making the conscious choice to buy or not buy enMotion brand paper towels or Von Drehle brand paper towels is the lessee of the enMotion dispensers. The lessee compares the look and feel of the different brand of paper towels, and compares the prices. The lessee then makes the purchase. Therefore, the relevant consumer is the lessee.

3. Is there direct trademark infringement? The Georgia-Pacific trademarks were not applied to or associated with the items there were the source of the alleged infringement, i.e., Von Drehle's 810-B Toweling. If the enMotion trademarks or similar had been used by Von Drehle (or the other defendants) on the packaging of the 810-B Toweling, or on the towels themselves, then a court would follow the usual trademark infringement inquiry. However, here the inquiry needs to follow the path of an indirect or contributory trademark infringement.

\footnotetext{
${ }^{69} I d$. at 453.
} 
4. Is there indirect trademark infringement? Remember that the analysis for contributory trademark infringement comes from the Inwood case, wherein the Supreme Court said that if a manufacturer or distributor intentionally induces another to infringe a trademark, or if it continues to supply its product to one whom it knows or has reason to know is engaging in trademark infringement, the manufacturer or distributor is contributorily responsible for any harm done as a result of the deceit. ${ }^{70}$ Again, the Fourth Circuit's analysis on this point is incorrect, primarily because the court believed that the restroom visitor was the relevant consumer, and therefore Von Drehle supplied paper towels to parties who it knew were engaged in trademark infringement (the "stuffers" of non-enMotion paper towels into enMotion dispensers).

Stepping back and reviewing the Georgia-Pacific cases from the perspective that the lessee is the relevant consumer, the analysis becomes more straightforward. The questions then to be asked are: Did the defendants use the trademarks of Georgia-Pacific in any manner? The answer is: no. Did the defendants encourage others to produce products that would use the Georgia-Pacific trademarks? The answer is: no. Did the defendants take any actions that would harm or cause confusion to the relevant consumer - the lessee? The answer is: no. Therefore, the Georgia-Pacific cases could have ended at this point with a verdict for the defendants.

For argument's sake, let us keep looking at the second step of the revised test.

B. Is there an assertion of rights for an improper purpose?

1. Is the trademark owner's primary goal to prevent confusion in the mind of the relevant consumer or market? Georgia-Pacific argued that its goal was to establish in the mind of the restroom visitor that only high-end paper towels would be dispensed from its enMotion

\footnotetext{
${ }^{70}$ Inwood Labs, 456 U.S. at 853-854.
} 
dispensers. $^{71}$ If the relevant consumer is defined as the restroom visitor, then Georgia-Pacific might have a legitimate argument. However, as stated above, the relevant consumer should be the distributors/lessees who actually make the purchasing decisions for the paper towels for use in the enMotion dispensers. Therefore, this question is answered, at least arguably, that the trademark owner's primary goal was not to prevent confusion in the mind of the relevant consumer, but to use the trademark(s) as a weapon to limit competition in consumables (i.e., the paper towels).

2. Is the intent of the owner to prevent others from: (a) using the goods that bear the trademark, (b) supplying consumables to the goods that bear the trademark, or (c) gaining access to the goods that bear the trademark? This wording is not intended to be a shorthand way to say that the maligned business plans of tying consumables to a trademarked product discussed above are all evil. On the contrary, a trademark owner may have a legitimate interest in limiting what may be added to or dispensed from or in conjunction with its goods. For example, Georgia-Pacific likened its leasing of its enMotion dispensers to Coca-Cola wanting to ensure that only genuine COKE soft drink was dispensed from soft drink machines labeled with the COKE trademarks. ${ }^{72}$ Obviously, Coca-Cola has a very keen interest in protecting its "good will" by ensuring that only genuine COKE soft drinks are dispensed. However, in looking at the Coca-Cola example, the analogy does not quite fit the Georgia-Pacific paper towel cases. With COKE, the consumer is a thirsty person looking for a soft drink to purchase. The consumer confronts a dispenser labeled COKE and decides to purchase a COKE brand soft drink or not. Assuming that the consumer wants to buy a COKE soft drink, the consumer expects a genuine COKE soft drink to be

\footnotetext{
${ }^{71}$ Von Drehle, 618 F.3d at 448.

${ }^{72} I d$. at 446.
} 
dispensed. However, in the Georgia-Pacific paper towel cases, the restroom visitors enter a restroom not looking to make a purchase. The restroom visitors are looking for, among other things, a place to wash and then dry their hands. A hot air hand dryer, a roll of kitchen paper towels, or a paper towel dispensed from a machine will all work just fine. Trademarks are not an issue!

On the other hand, when the enMotion lessee needs to refill the enMotion paper towel dispenser, the lessee is looking to make a purchase. Trademarks on or associated with the goods to be purchased (i.e., the paper towels) can play an important part in the purchaser's decisionmaking process. Specifically, does the lessee think that paying more for enMotion-brand paper towels is worth it versus paying less for Von Drehle's 810-B Toweling? This discussion further bolsters the finding that the relevant consumer for the trademark infringement analysis is the lessee - not the restroom visitor.

The last question to ask is: Was the trademark owner (Georgia-Pacific) using its trademarks in an attempt to prevent others (the distributor/lessee) from supplying (refilling or "stuffing") consumables to the goods that bear the trademark (the enMotion dispensers)? The answer to this question is: yes. Therefore, in the Georgia-Pacific cases, the enMotion trademarks were used as a legal weapon to accomplish a business goal apart from protecting the consumer; specifically, for eliminating competition for the refilling of paper towels into the enMotion dispensers. A finding of trademark misuse would be appropriate, and the trademark owner would be enjoined from asserting its marks against the defendants. 


\section{Conclusion}

Manufacturers of products that require replacement parts or the refilling of supplies ("consumables") have long sought ways to tie the purchase of the consumables to - and only to that manufacturer. In the recent trademark cases brought by Georgia-Pacific, ${ }^{73}$ Georgia-Pacific sued competitors that made and/or installed lower-price paper towels sized to fit into GeorgiaPacific's enMotion-brand paper towel dispensers. Georgia-Pacific's trademarks were not used by the competitors in any way, yet Georgia-Pacific used the doctrine of contributory trademark infringement against them. This article provides an equity-based test that can be used by courts to eliminate trademarks being improperly used to establish a tying relationship for consumables. The proffered test remains true to the principles of trademark law by focusing first and foremost on protecting the consumer, as opposed to focusing - as the trademark owners would suggest on protecting the trademark "property", or - worse - on using trademarks as a weapon to establish a tying relationship for consumables. Before the type of trademark misuse advocated by Georgia-Pacific gets out of hand, it is time to revisit and implement the doctrine of trademark misuse.

${ }^{73}$ See Von Drehle, 618 F.3d 441 (4 ${ }^{\text {th }}$ Cir. 2010); Myers Supply, 621 F.3d 771 ( $8^{\text {th }}$ Cir. 2010). 